\title{
ESSAYS
}

\section{Lessons for International Law from the Gulf War}

\author{
Paul W. Kahn*
}

Politically and militarily, the War in the Gulf remains an unsettled event. Although nearly two years have passed since the War, its political consequences are still evolving. Militarily, the recent reintroduction of allied forces into Iraqi air space suggests that the War continues, though at a much reduced level. ${ }^{1}$ In the long run, the War will probably be seen as a footnote to the larger political upheavals that marked the start of this decade-noteworthy because it made visible the realignment of the international order that had already occurred.

While the War may be merely a footnote from the perspective of political history, it is a major event from the perspective of international law. It marked one of the few occasions on which there was a deliberate invocation of international law to justify military force. For this reason, an examination of the War can teach us much about the reality of, and possibilities for, international law. Given the continuing tumultuous politics of Eastern Europe and the former Soviet Union, this legal reconsideration is important. Already, the international-legal machinery deployed in the War has served as a precedent for United Nations Security Council action authorizing military intervention in Bosnia and Hercegovina. ${ }^{2}$

We are moving rapidly toward a new world order of some sort. While it may be too early to predict the political shape of that order, it is not too early to consider the role that international law may play in it. Before we raise our hopes for a vital future for international law, we need to fully understand the character and power of existing international law. To that end, it is useful to examine international law as it operated, and failed to operate, in the Gulf War.

The international law at work during the Gulf War is the captive of an

\footnotetext{
* Professor of Law, Yale Law School. at $\mathrm{A} 1$.

1. See, e.g., John Lancaster, Allies Declare "No Fly Zone" in Iraq, WASH. Post, Aug. 27, 1992,

2. The U.N. Security Council authorized states "to take . . . all measures necessary to facilitate ... delivery ... of humanitarian assistance to . . Bosnia and Hercegovina." Statement Authorizing Intervention in Bosnia and Hercegovina, U.N. SCOR, -Sess.,- mtg. at-, U.N. Doc. S/PV(Aug. 13, 1992) (on file with the Stanford Law Review).
} 
ideal of state sovereignty that assumes a harmonious relationship between a people and its government. All too often, however, the reality is not harmony but opposition. In its present form, international law cannot deal with this reality. Its focus on the ideal of state sovereignty leads international law to pursue morally unsupportable goals and to choose irrational means. When the international legal system acts to protect state sovereignty, too often the only real beneficiary is the political leadership, not the people. In those rare cases when modern international law responds to legal violations, it ends up punishing the people for the acts of their leaders, when the people too are victims.

While at some deep level international law has grasped that it will remain a tool of powerful interests of the status quo until it rests on a foundation of human rights, justice, and equality, these ideals are not yet operative aspects of the legal system. Until the international legal system embraces these ideals, the new world order must seek a foundation somewhere outside of international law.

These may seem overly pessimistic conclusions to draw from the defeat of Saddam Hussein's effort at international aggrandizement. Admittedly, the enterprise of drawing general lessons for international law from a single event is inherently controversial. Moreover, analysis of the Gulf War is particularly difficult because the events have a complicated sequential character. The lessons drawn depend not only upon the particular events one emphasizes, but equally upon where one ends the story. For example, although the immediate aftermath of the war was a human rights disaster for Iraqi Kurds and Shiites, that disaster elicited an international response that is itself an ongoing story.

Despite such problems, international legal analysis must look to single events. This is true because particular incidents of state behavior are an important source of innovation in international law. ${ }^{3}$ More important, only by looking to the operation of law in particular events are we able to discuss realistically the force and effect of the formal system of international law. ${ }^{4}$

Discussion of international law, particularly the law of war, always occurs within a context generated by a single, overwhelming question: Is international law really law at all? Although international lawyers believe they have answered this question countless times, the truth is that international law can no more escape this question than constitutional law can escape the question of the legitimacy of judicial review. These questions define the enterprises: They reveal the deep ambivalence we feel about the ties between legal institutions and the political order. Analysis of the Gulf War shows that this ambivalence permeates the very norms of international law.

Because the War was a complex event spread out over many months,

3. See Statute of The International Court of Justice, art. XXXVIII, § 1 (listing "international custom" as a source of international law).

4. See W. Michael Reisman \& Andrew R. Willard, International incidents: The Law That Counts in World POlitics (1988). 
three different perspectives on the role of international law will assist the analysis. We can look to the role of law in the actions leading up to the War, in the conduct of the War, and in the aftermath of the War. Together, these perspectives illustrate how modern international law manages (or fails to manage) a crisis.

\section{GoING TO WAR}

From the perspective of international law, rather than U.S. policy, the War did not begin on January 16, 1991 with the initiation of the bombing campaign; rather, it started on August 2, 1990 when Iraqi troops crossed Kuwait's border. Undeniably, Iraq's invasion of Kuwait represented a massive failure of international law. Whatever Iraq might have said about $\mathrm{Ku}$ wait being a province of Iraq, no one can deny that sending the Iraqi army across the internationally recognized border of Kuwait was a violation of the first and most evident principle of modern international law. This principle is set down in Article 2(4) of the U.N. Charter: "All members shall refrain in their international relations from the threat or use of force against the territorial integrity or political independence of any state . ..."s

The Iraqi invasion marked the first time that one U.N. member state attempted to use military force to obliterate the sovereignty of another member state. Although states have, of course, regularly intervened in the domestic affairs of other sovereign states, they have not aimed to terminate sovereignty through annexation. Kuwait and Iraq may indeed have had a longstanding territorial dispute, ${ }^{6}$ but modern international law rests on the premise that states are to seek resolution of their disagreements through peaceful means rather than recourse to force. ${ }^{7}$

Iraq's actions resembled those common throughout the pre-United $\mathrm{Na}$ tions international legal system, in which force was regularly used to change territorial boundaries. In that system, war was a legitimate way to change legal relationships, including geographic borders. ${ }^{8}$ The modern system of international law, represented in the U.N. Charter, insists that changes in the existing legal regime can arise only through peaceful mechanisms that rest ultimately on the consent of sovereign states. Accordingly, Chapter VI of the Charter, on "pacific settlement of disputes," allows the Security Council to do no more than "recommend" procedures for and terms of settlement. ${ }^{9}$ Chapter VII which allows the Security Council to take coercive

5. U.N. CharTER art. 2, ๆ 4.

6. On the history of the territorial dispute between Iraq and Kuwait, see Richard N. SCHOfield, Kuwait and IraQ: Historical Claims and Territorial Disputes (1991).

7. See U.N. Charter art. 2, I 3 ("All members shall settle their international disputes by peaceful means . . ..").

8. See Lasa Oppenheim, International Law § 241a (H. Lauterpacht ed., 7th ed. 1948):

The recognition of title by conquest was, prior to the Covenant of the League, the Charter of the United Nations, and the General Treaty for the Renunciation of War, the necessary result of the admissibility of the right of war as an instrument both for enforcing the law and for changing existing rights.

9. U.N. ChARTER arts. 33-38. 
action, envisions such action only "to maintain or restore international peace and security." 10 The Charter authorizes action, in other words, only when there has been, or is about to be, a violent breach of the legal status quo. Changes brought about by a unilateral use of force are, therefore, no longer entitled to legal recognition. ${ }^{11}$

Although it shocked many international lawyers, Iraq's August invasion at least shed the ordinary patina of hypocrisy associated with state uses of force in the modern era. The manipulation of legal rhetoric had already corrupted the modern international legal system. Iraq's lawlessness brought us face-to-face with this corruption. That Iraq could have even invaded $\mathrm{Ku}$ wait represents the failure of international law, as of August 1990, to provide a substantial restraint on the use of military power to create a regional, hegemonic position. Surely this was not new. What was new was Iraq's disregard of the rhetoric of international law.

While violations of international law's prohibition on the use of force have been frequent in the modern era, they have generally been accompanied by efforts at legal justification. These asserted justifications have ranged from "invitations" to intervene, to "collective" decisions by regional organizations, to simple denials of responsibility for "covert" actions. ${ }^{12}$ Rarely have these justifications and excuses been anything more than pretexts for aggression. At best, they have provided a weak acknowledgment of the presence of an international legal system that forbids the employment of force against a sovereign state. Iraq's invasion of Kuwait teaches that the reality of unilateral state intervention provided a stronger rhetoric, to all but the lawyers, than the covering rhetoric of international law.

Moreover, Iraq had good reasons to believe it could safely disregard both the form and substance of international law. When had the international community expended substantial resources to protect the sovereignty of one of its members? Looking to the modern history of the Middle East, Iraq would have found very little evidence that the international behavior of states was subject to an effective regime of law. The world stood by when Iraq invaded Iran. Indeed, it is now clear that the United States and a number of its allies actually assisted Iraq in that war as early as the Spring of 1982. ${ }^{13}$ Similarly, while the international community may have called the

10. U.N. CHARTER arts. 39-51.

11. An early, and unsuccessful, effort to formulate this position was the Doctrine of Nonrecognition, proposed by Secretary of State Stimson in 1932 (the "Stimson Doctrine"), which would have refused to recognize "any situation ... which may be brought about contrary to the covenants and obligations of the Pact of Paris." J.L. Brierly, The LAW of Nations: AN INTRODUction to The International LaW of Peace 172 (Sir Humphrey Waldock ed., 6th ed. 1963). The Pact of Paris (1928), in turn, purported to make illegal "recourse to war for the solution of international controversies." Id. at 409.

12. This was seen in the Soviet intervention in Afghanistan (in response to an alleged "invitation"); the U.S. intervention in Grenada (based allegedly on both a collective decision of the Organization of Eastern Caribbean States as well as an invitation); and the U.S. intervention in Nicaragua (repeated denials of responsibility for covert actions).

13. See Seymour M. Hersh, U.S. Secretly Gave Aid to Iraq Early in Its War Against Iran, N. Y. TIMES, Jan. 26, 1992, at A1 ("The Reagan Administration secretly decided to provide highly classi- 
Syrian and Israeli military interventions in Lebanon illegal, both countries still occupy substantial portions of Lebanese territory. The international community had also failed to take any practical action to force Israel to change its policy of occupation and annexation of the territories captured in the 1967 war. In sum, international law, beyond an occasional rhetorical flourish, was not an effective rule of action in the Middle East.

On all sides of disputes in the Middle East, force, not law, has determined behavior. Success and failure have been determined on the ground and in the streets, not in the legal institutions of the international system. Quite simply, formal condemnation of international law violations has not counted for much. Iraq would have easily tolerated this foreseeable cost.

Expanding the horizon of international behavior, Iraq could again have reasonably concluded that the world was quite willing to tolerate military intervention by regional powers. The list of violations of Article 2(4) is long indeed. For example, in this hemisphere, recent years have seen forceful U.S. interventions in Nicaragua, Panama, and Grenada. Around the world, examples include the Soviet Union's invasion of Afghanistan, not to mention its earlier interventions in Eastern Europe, China's intervention in Vietnam, Vietnam's intervention in Cambodia, and South Africa's interventions in Angola and Mozambique. All of these actions raise the possibility that the Charter's grand vision of international law, expressed most clearly in Article 2(4), suffered an early death. ${ }^{14}$

Iraq's action was more dramatic in appearance than the previous examples in that it denied Kuwait sovereignty. Nevertheless, it is difficult to argue that the international community had, in the period since the end of World War II, established the principle of nonuse of force as a practical constraint on interstate relations. The events of the summer of 1990 demonstrate the dimensions of the failure of the international law project of the modern era. What was aberrational about those events was the world's response, not Iraq's action. But a unique response cannot change the place of law in the international order overnight. The Gulf War is, above all, a story of international law's failure, not of its success.

Moreover, before international lawyers go too far in their celebration of the collective response to Iraq's aggression, they should assess realistically exactly where Saddam Hussein made his mistake. His was a political, not a legal mistake. Put bluntly, Saddam Hussein was too greedy. The strategic nightmare for the United States would have been for Saddam Hussein to have pulled out of Kuwait completely, except for a narrow strip of land along the border and the two Kuwaiti islands of Warba and Bubiyan. This strip, of course, contains most of Kuwait's oil. Obtaining the islands would also have secured Iraq's outlet to the Gulf. Moreover, these areas were at

fied intelligence to Iraq in the spring of 1982-more than two years earlier than previously disclosed-while also permitting the sale of American-made arms to Baghdad in a successful effort to help President Hussein avert imminent defeat in the war with Iran.").

14. $\rightarrow$ Thomas M. Franck, Who Killed Article 2(4)?, 64 AM. J. INT'L L. 809 (1970). 
the center of the historical dispute between Iraq and Kuwait. These territories are what many observers believed to be the strategic goals of Iraq. ${ }^{15}$ Nevertheless, it is inconceivable that the United States could have mobilized an international coalition, or even substantial domestic support, for military action to respond to what would have been seen as merely a new twist in a longstanding border dispute between Iraq and Kuwait. In fact, it is doubtful that the United States could have mobilized even a nonmilitary response. The world, I suspect, would have been willing to tolerate a good deal of lawless behavior even in this instance. There is a lesson in political moderation to be found here, as much if not more than a lesson in law.

If Iraq's actions in going to war demonstrate international law's failure in the modern order, the international response provides a counter-study in the possibilities for law. The modern system of international law emerged in response to the extreme levels of state violence that marked the first half of this century. The goal of post World War II international law was not just to regulate the conduct of war, but to end war altogether. ${ }^{16}$ Interstate violence under the new system was to be either a violation of law or the sanction of law in response to a prior violation. Crucial to this legal system is the operation of collective decisionmaking by international institutions acting under legal standards. Yet for most of the modern era, those institutions have failed to act. Because the formal system of law did not coincide with the political interests of the major powers, international law's formal prohibition against the use of force remained, for the most part, an unrealized ideal. ${ }^{17}$

By going to the United Nations and following the procedures for collective decisionmaking set forth in the Charter, the United States built an international law framework for its actions. While there was ample recent precedent for Iraq's disregard of international law, one must go back to the Korean War and the Cuban Missile Crisis to find adequate precedents for the United States' decision to mobilize the institutions of international law to support a recourse to force. Security Council action in the former case, and OAS action in the latter, converted interstate violence and the threat of violence into the positive expression of an international legal regime. The same was true in this case: Force was linked to law through an international decisionmaking mechanism. ${ }^{18}$

15. See Theodore Draper, The Gulf War Reconsidered, N.Y. REv. Books, Jan. 16, 1992, at 46, 47-48.

16. See U.N. Charter pmbl. ("We the Peoples of the United Nations determined to save succeeding generations from the scourge of war. ...").

17. The symbol of this mismatch between international law and politics was the complete failure to act on Article 43 of the U.N. Charter, which imagined an institutionalization of military power within the United Nations, to provide an effective international sanctioning mechanism.

18. To appreciate the unusual character of the U.S. action in this case, we might compare it to the long policy of secret, unilateral intervention in Nicaragua or to the strained legal arguments in support of intervention in Grenada and Panama. For a discussion of the conflict in Grenada, see

$\rightarrow$ Francis A. Boyle, International Lawlessness in Grenada, 78 AM. J. INT'L L. 172 (1984). On Panama, $\rightarrow$ Ved P. Nanda, The Validity of United States Intervention in Panama under International Law, 84 AM. J. INT'L L. 494 (1990). 
From the perspective of creating an effective international legal regime, the United States' action with respect to Iraq is particularly praiseworthy because a strong argument could have been made in support of unilateral action under Article 51 of the Charter. That Article recognizes a right of self-defense and, more importantly, of collective self-defense "until the Security Council has taken measures necessary to maintain international peace and security." 19 Arguably, the United States could have defended Kuwait and Saudi Arabia merely upon a request from their governments. This exception for a unilateral recourse to force in "self-defense" has provided a large loophole through which much of the hope for the prohibition on the use of force in Article 2(4) has fallen over the last few decades. Yet another unilateral use of force, justified by reference to Article 51, would have done little to advance international law from a self-serving rhetorical system to an actual restraint on the behavior of states.

Discussions of international law tend to fade into discussions of the domestic law of foreign policy. This is inevitable for two reasons. First, we are interested not just in the formal system of international law but in how international law interacts with domestic legal institutions. Second, international law and constitutional law both address the problem of creating institutional constraints on the unilateral use of force in international affairs. ${ }^{20}$ International law and domestic separation of powers doctrine share the goal of restraining the use of force through the dispersion of authority and the requirement of collective decisionmaking. Not surprisingly, therefore, the Gulf War triggered renewed debate over the constitutional division of responsibility for decisions to use force: Does Congress' war-making power require it to review military actions taken by the President as commander in chief ?21

Just as there is a danger in looking only to the international response to Iraq's action and not to that action itself in evaluating the contemporary status of international law, so too is there a danger in looking only to Congress' ultimate approval of the President's actions, rather than its initial failure to act at all, in evaluating the constitutional dimensions of the problem. In truth, the Gulf War reveals more about congressional impotence than about joint executive and legislative responsibility for foreign policy.

In recent history, Congress has repeatedly failed to effectively check executive decisions to use force. ${ }^{22}$ Congress' behavior in the Gulf War confirms that pattern. Congress allowed itself to be manipulated by the

19. U.N. CHARTER art. 51.

20. See Philip Bobbitt, Constitutional Interpretation 72-81 (1991); Harold Honguu Koh, The National Security Constitution: Sharing Power After the IranCONTRA AfFair 67-100 (1990).

21. These issues took legal form in Dellums v. Bush, 752 F. Supp. 1141 (D.D.C. 1990), a lawsuit by several members of Congress who requested an injunction to prevent President Bush from initiating an offensive attack against Iraq without first securing Congressional authorization. The court determined that the controversy was not ripe for judicial decision. Id. at 1152 .

22. $\rightarrow$ Harold Hongju Koh, Why the President (Almost) Always Wins in Foreign Affairs: Lessons of the Iran-Contra Affair, 97 Y ALE L.J. 1255 (1988). 
President, who was able to control both the agenda and the calendar. If Congress was to act effectively, it needed to act early-October or November at the latest. During this period, however, there was no congressional policy. Instead, there was a conscious effort by congressional leadership to avoid taking a position. Congress thereby allowed the President to build up U.S. forces and create a major confrontation with Saddam Hussein without subjecting those policy choices to public scrutiny and articulate critique. Indeed, the entire November election passed without a serious public evaluation of these policies. When the President finally turned to Congress for support, Congress found itself in a position where any attempt to constrain U.S. military policy would have seemed like a concession to Iraq.

The lesson that constitutional theorists should learn from this is that Congress, in an age in which the President effectively controls much of the media, is not likely to provide the constraint on military action for which the Founders had hoped when they placed the war-making power in Congress' hands. ${ }^{23}$ In truth, decisions to use military force are usually quite popular. No President is likely to suffer politically from a successful use of force, even if it violates international law. The President has a unique capacity to mobilize popular support and to lead the country in these situations. Congress does not, at those moments, have the political strength to say no to the President. Indeed, the lesson that Congress may have learned from the military success of Desert Storm is that it is extremely risky to oppose the President on decisions to use force. Military action becomes unpopular only when it goes badly. By that time, congressional action is usually too little and too late.

In the Gulf War, both sets of institutional authorities-domestic and international-acted on and approved the use of force in response to Iraq's invasion. International institutions were strengthened by their actions, but Congress was not strengthened in its ongoing struggle with the President. This conclusion is supported by more recent events. In the past year, the President has threatened to use force in what was formerly Yugoslavia and has reintroduced American combatants into Iraq. Neither policy was debated or acted upon by the Congress. In the former instance, however, the President did seek United Nations' approval of possible military intervention.

The larger lesson is that if there is to be an effective institutional means of constraining military adventurism, at least by the United States, it must be located in the international arena. The danger of the "new" world order is that it will simply replace a system of two superpowers with that of a single superpower. If that comes to pass, the most pressing need of the new order will be to devise mechanisms to constrain the use of military force by U.S. Presidents. In this context, the Gulf War is useful as a paradigm of what

23. The lesson President Bush drew from this experience seems to have been that he did not need congressional approval for his use of force in the Gulf: "It was argued I can't go to war without the Congress. And I was saying, I have the authority to do this." 27 WeEkLy Comp. Pres. Doc. 284 (Mar. 10, 1991). 
international law requires before a country, including the United States, can use military force against another country. That it has served this role in the development of policy with respect to the conflict in Bosnia is a hopeful sign. That it will continue to be an effective paradigm is, at least, doubtful.

The circumstances that allowed the United States to muster international support for its military action in the Gulf were quite exceptional. Both the Soviet Union and China were so preoccupied with their own domestic problems, and with their relations with the West, that they were unwilling to exercise their veto power in the U.N. Security Council to defend a former client state. In addition, European and Third World dependence on Middle Eastern oil contributed to Iraq's isolation in the international arena. While these particular circumstances made the international cooperation in the Gulf War both attractive and plausible, this confluence of events is unlikely to repeat itself in the future. Even in this case, the United States still had to mobilize massive political and economic resources to achieve the desired results at the United Nations. ${ }^{24}$ Thus, the experience of the Gulf War offers little reason to hope that the United States (or any other state) will choose a less compliant multinational decisionmaking process over a unilateral recourse to force if national security interests are threatened in the future. In this respect, the most telling fact about recent international actions with respect to Bosnia may be that despite the Security Council action, no country has yet had sufficient motivation to intervene.

In the end, the use of force in the Gulf War teaches first a lesson of the failure of international law and then a lesson of the potential of international law. The failure reflects the dominant pattern of modern international affairs-a unilateral recourse to force without regard to legal constraints. The positive response of the international community, however, is one of a limited number of successful efforts at collective decisionmaking under the U.N. Charter. To interpret this response as the beginning of a new respect for international law is, I am afraid, far too optimistic.

\section{THE CONDUCT OF THE WAR}

Just as Iraq disregarded international law by invading Kuwait, it showed little respect for international laws governing warfare. ${ }^{25}$ The conduct by both sides, however, demonstrates the inadequacies of the current international law of warfare. First, the legal system failed to deter Iraq from committing massive human rights abuses. Second, basic tenets of international law, such as proportionality of military response, failed to provide any real limits on allied action. Third, and most important, compliance with the in-

24. See Theodore Draper, The True History of the Gulf War, N.Y. REV. Books, Jan. 30, 1992, at 38,41 .

25. See U.S. Department of Defense, Report to Congress on the Conduct of the Persian Gulf War-Appendix on the Role of the Law of War, Apr. 10, 1992, 31 I.L.M. 612 (1992) [hereinafter DoD REPORT]. 
ternational law of warfare does not in itself minimize the human suffering that attaches to war.

During the Gulf War, Iraq violated various provisions of the $1949 \mathrm{Ge}-$ neva Conventions on the treatment of prisoners of war and on the treatment of civilians in occupied territories. Iraq's taking of foreigners as hostages, its seizure of Kuwaiti civilians, its systematic looting of the country, its massive human rights violations within Kuwait, and its treatment of allied prisoners of war all violated the most basic of international law norms. Is anyone surprised by this? Where would Iraq have learned the habits of legality?

The international community has failed to create an environment in which the rule of law functions as a general norm by which to measure state behavior. The Middle East has been a lawless, violent place. Saddam Hussein's behavior within Iraq has not been significantly different from the behavior of surrounding regimes, including Syria, Iran, and even Israel in many respects. In these states, the concern for human rights, self-determination, and principles of justice-ideals necessary to support any legitimate legal system-are simply absent from governmental policy.

It is unrealistic to expect regimes that do not adhere to a rule of law in their domestic policies to do so internationally. Although tactical interests may dictate compliance with international law, that depends on the everchanging political and military circumstances. The mere fact that a rule is a product of law does not give it independent or additional weight for these regimes. Law is either a habit of governance or it is not. In the Middle East, it is not.

Interestingly, the one rule of warfare which Iraq appeared to abide by was that on the nonuse of chemical weapons. ${ }^{26}$ The lesson may be that reciprocity is still the most effective enforcement mechanism for the rules of warfare. Iraq must have feared that it would have suffered massive retaliation had it used chemical weapons. In particular, if it had used chemical weapons against Israel, Iraq could realistically have feared not simply a reciprocal use of gas, but also an Israeli nuclear response. On the other hand, Iraq could reasonably have concluded that whatever it did to Kuwaiti citizens, or even to allied POW's, the allied forces were not likely to respond in kind.

Given that allied reprisals were not likely-indeed, they are specifically prohibited by $1 \mathrm{law}^{27}$-the only possible deterrent was the threat of criminal prosecutions for war crimes. President Bush acknowledged this possibility before the conflict. ${ }^{28}$ Nothing, however, has come of it. The judicial traves-

26. See Protocol for the Prohibition of the Use in War of Asphyxiating, Poisonous or Other Gases, and of Bacteriological Methods of Warfare, June 17, 1925, 26 U.S.T. 571, 94 L.N.T.S. 65.

27. See Geneva Convention Relative to the Treatment of Prisoners of War, opened for signature Aug. 12, 1949, art. 13, ๆ 3, 6 U.S.T. 3316, 3328, 75 U.N.T.S. 135, 146; Geneva Convention Relative to the Protection of Civilian Persons in Time of War, opened for signature Aug. 12, 1949, art. 33, 6 U.S.T. 3516, 3538, 75 U.N.T.S. 287, 308.

28. In October 1990, President Bush issued a public warning to Saddam Hussein that he could be held legally accountable for war crimes. DoD RePorT, supra note 25, at 634; Dan Balz, President Warns Iraq of War Crimes Trials, WASH. Post, Oct. 16, 1990, at A19. 
ties that occurred in Kuwait following the War undermined whatever possibility there was of war-crime trials. Any such action would have appeared as "victors' justice" rather than the enforcement of a rule of law applicable to all parties to the dispute.

In contrast, it is probably fair to say that the United States and allied forces conducted their operations in accordance with international law. ${ }^{29}$ Some have voiced objections that the allied bombing campaign violated the law of proportionality, but this standard is the weakest of all international law norms. ${ }^{30}$

The concept of proportionality-which holds that responsive uses of force "must not exceed in manner or aim the necessity provoking them" 31 invites endless argument. Arguably, the United States did nothing more than was necessary to defeat Iraq in a four-day ground war. Of course, that argument rests on the critical assumption that a four-day ground war was the appropriate response to Iraq's actions. Should the United States have been willing to exercise a great deal more patience, if that meant considerably less suffering for Iraqis? Should it have been willing to adopt methods of warfare that would have jeopardized the success of the enterprise or risked greater injury to allied troops?

There can never be a convincing measure of proportionality as long as the two sides of the equation are incommensurable. In this instance, the sovereignty of a state was at issue. But sovereignty is not a relative value in the system of international law. Rather, it is the foundation or starting point of the whole system. By the standards established by international law, the value of state sovereignty is incalculable. From this it follows that the idea of proportionality makes no sense whenever state sovereignty is at issue in a dispute. ${ }^{32}$

More important, proportionality is impossible to measure as long as sovereign states place different values on the lives of their own citizens and those of the enemy state. Yet, if all life were valued equally, no one would ever go to war. War rests on an asymmetrical valuing of human life that runs directly counter to the logic of a rule of proportionality.

How many American lives, then, should we be willing to lose in order to protect Iraqis? No one knows how to answer this question. The standard of proportionality, at best, points to a discretionary judgment that will be made differently by each side to the dispute. To be an effective legal standard, it would require application by a neutral adjudicator in which the power of discretion could be vested-just as when domestic courts are called upon to

29. See, e.g., DoD REPORT, supra note 25 , at $615,617,620-24,626-27$.

30. See Ramsey Clark and others, War Crimes: A Report on United States War Crimes Against IraQ 44, 53 (1992).

$\vdots \rightarrow$ Oscar Schachter, The Right of States to Use Armed Force, 82 Mich. L. REv. 1620, 1637 (1984).

32. One clear example of this "incomensurability" is a policy of self-defense that relies upon the threat of a strategic nuclear response. Mutual assured destruction is a policy in which this incomensurability appears as the total disjunction between means and ends. 
make determinations of "reasonableness" based on incommensurable values. Yet such adjudicators are precisely what the international system lacks. Nothing that occurred in the Gulf War should make us more hopeful about the future in this regard.

In the absence of an independent adjudicator, each party must make its own judgments of legality. While some scholars have argued that international law works precisely through such decentralized decisionmaking, ${ }^{33}$ it is safe to say that the only judgment that will be recognized as legitimate is that the allies conducted their operations in accordance with international law while Iraq violated it. Yet, we must still ask what lesson other states are likely to draw from this proposition. Does the international law of warfare appear reasonable? Is it a system of law that is likely to gather increasing respect? Whose interests does it protect?

The overwhelming lesson of the conduct of the Gulf War is that there is no direct correlation between complying with international legal rules and minimizing suffering. Even while the allies arg!lably complied with the legal norms, they inflicted massive suffering upon the Iraqi people. Estimates of Iraqi fatalities range up to 100,000 soldiers, ${ }^{34}$ as well as a significant number of civilians. ${ }^{35}$ Iraq's infrastructure was largely destroyed. ${ }^{36}$ In the year following the War, Iraq's child mortality rate was reported to have tripled. ${ }^{37}$ The international community continues to monitor possible outbreaks of disease and hunger. How long it will take for Iraq to fully recover its position as a modern state is anybody's guess.

The suffering permitted within the rules of international law is stunning. International law's concern with proportionality runs only to the relationship between this suffering and the goal of reestablishing Kuwaiti sovereignty. International law, as we have seen, has no way of balancing this equation. More important, it is not concerned with the disproportionality between the suffering on the Iraqi side and the minimal burden on the allied side.

The West was enraged when a few allied pilots were paraded on Iraqi television. This was, it is true, a clear violation of international law. ${ }^{38} \mathrm{Nev}-$ ertheless, the lives of tens of thousands of Iraqis were being destroyed at the same time-wholly within the parameters of international law. While inter-

33. See, e.g., Myres S. McDougal, Harold D. Lasswell, William T. Burke, Florentino P. Feliciano, Richard N. Gardner, Asher lans, Gertrude C. K. Leighton, Leon Lipson, \& Norbert A. Schleig, Studies in World Public Order 8-15 (1960).

34. Anthony Cordesman, The Persian Gulf War: An Analysis, in The World Almanac AND Book of FACTs 35, 37 (Mark S. Hoffman ed., 1992) (citing U.S. Intelligence estimates).

35. Caryle Murphy, Iraqi Death Toll Remains Clouded; Baghdad Promises Figures, Wash. Post, June 23, 1991, at A1.

36. Id. at 38; see also Middle East Watch, Human Rights Watch, Needless Deaths IN THE GULF WAR 171-93 (1991). at A4.

37. See Don Shannon, U.S. Denies Blame for Malnutrition in Iraq, L.A. TIMEs, Oct. 23, 1991,

38. See 1949 Geneva Convention Relative to the Treatment of Prisoners of War, supra note 27, art. 13, ๆ 2, 6 U.S.T. at 3328, 75 U.N.T.S. at 146 (protecting prisoners of war from "insults and public curiosity"). 
national law condemns Iraq's seizure of the hostages, it virtually ignores the massive numbers of Iraqi civilians-let alone a largely conscript army-that suffered the effects of the Gulf War.

International law in its present form shows more concern with antiquated concepts of chivalry among combatants than with the modern reality of mass destruction. The rules of war do not adequately reflect the reality of warfare between a third-world country and a superpower. Compliance with the rules of war is a prescription for disaster. This lesson was learned a long time ago in places such as Vietnam and Afghanistan. To assert that massive aerial bombardment - with its inevitable civilian casualties-complies with the international laws of warfare, but that reciprocal efforts by a third-world country to put civilian populations at risk violate international law only reveals one's own political interests. One cannot take this position and realistically expect the international legal system to gain the respect of countries that are more likely to be the victims than the allies of great powers.

The international law that governs the conduct of war is ultimately a system designed to protect the self-interests of the more powerful states. Rules that do not treat all lives equally cannot, in the long run, support an international legal system. The 1977 Protocols to the Geneva Conventions begin to address this imbalance; ${ }^{39}$ not surprisingly, the United States has refused to agree to such changes.

In light of this imbalance, one of the oddest aspects of Iraqi behavior during the War was its action with respect to the foreign hostages whom it held during the first several months of the crisis. Holding the hostages was an obvious violation of international law, but was perversely rational. In contrast, Iraq's decision to release the hostages was puzzling. It is doubtful that the air campaign against Iraq would have taken the same form had foreign hostages remained at a number of military and industrial installations. One lesson of this War, therefore, might be: Don't give up your hostages.

\section{THE WAR'S AFTERMATH}

Assuming that the allied effort was initiated and conducted within the norms of international law, we must still ask what international law sought to achieve by mobilizing and approving this use of force. In one sense the answer is obvious: The goal was the reestablishment of the sovereign state of Kuwait, a member of the United Nations and a possessor of international legal rights. But why protect Kuwait? Kuwait, by anyone's standards, hardly embodied a just regime. Defending that regime did not mean protecting the human rights and self-determination of the Kuwaiti people. If that

39. For example, Article 44 of the 1977 Geneva Protocol I offers legal recognition to nonregular or guerilla forces and Article 1 extends the rule of international law into some areas of armed conflict that had previously been governed by domestic law or fallen within a state's jurisdiction. Protocol Additional to the Geneva Conventions of 12 August 1949, and Relating to the Protection of Victims of International Armed Conflicts, opened for signature Dec. 12, 1977, arts. 1, 44, 16 I.L.M. 1391-92, 1396, 1410. 
was not clear before the War, it has surely become clear in the War's aftermath. ${ }^{40}$

Was the goal of the War nothing more than the substitution of one unjust regime for another? One regime was domestic and the other foreign, but was this goal worth so much sacrifice and destruction? How many lives were worth sacrificing for the ruling family of Kuwait? When we ask this question from the perspective of international law, we cannot simply measure U.S. lives. Was Iraq's destruction worth the benefit to the international community of saving the Kuwaiti regime? Does the answer change if we define the goal as the saving of Kuwaiti sovereignty? Sovereignty is only a formal legal quality that may or may not-depending on the circumstances-support a morally valuable goal. Regardless of how we define the value pursued, we must also determine the degree to which we are willing to hold the Iraqi population accountable for the actions of the Iraqi regime. The Iraqi people were not asked if they wanted to invade Kuwait. But surely they were held accountable.

Of course, international law only permitted-it did not compel-the use of force in the Gulf War. Nevertheless, international law legitimized the choice to go to war. Once the procedures and standards that allowed this choice were established, international law had no way of evaluating the choice when it was made. The character of the Kuwaiti regime simply dropped out of the equation; just as the suffering of the Iraqi people disappeared.

The allies' response during the Gulf War presents more than a question of the end failing to justify the means. Rather, the problem goes to the very foundation of the system of international law, which is organized around an ideal of state sovereignty. Because of this, it can deal only partially and inadequately with the crucial elements of the state: the people and the government. When these elements are in tension, as they often are, international law's concern with the state results in punishing the people for the actions of a government for which they cannot justly be held accountable. This was the problem of Iraq.

The situation in Kuwait represents the opposite problem. There, the defense of the state became the defense of the interests of the existing regime, which diverged from the interests of the people. In short, all too often the people bear the burdens of international law, while the regime reaps the benefits.

This pattern is not accidental. Although international law is a formal system that structures relations among states, it is created and maintained by governments. As long as the only voices heard within the system of international law are those of state governments, the system is not likely to be reformed. Humanity itself-the people who suffer the injuries-must be brought into the system. Doing so, however, would directly contravene the

40. See Caryle Murphy, Kuwait Reported Moving to Curb Rights Abuses, WASH. Post, Oct. 2, 1991, at A30. 
self-interests of the state governments that create and maintain international law.

The same confusion among states, peoples, and governments was evident in the international response to the internal uprisings in Iraq immediately following the War. Iraq surely did not take any lesson in legalism from its military defeat in Kuwait. Instead, it unleashed the same violent force it had used against Kuwait on its own minorities. Once again, Iraq tested the limits of modern international law, which for two generations has struggled to give some legal protection to human rights.

Having expelled the Iraqis from Kuwait, international law-and the forces mobilized on its behalf-seemed to have nothing more to say. The allies' first response was to allow the Iraqis a free hand to brutally suppress segments of their own population. Instead of focusing on human suffering and political justice, allied discussion focused on technical distinctions between aircraft and helicopters and on exactly what was said among the generals negotiating Iraq's withdrawal from Kuwait. Justice and human rights seemed not to be the operative terms of international law. The United States stood by and watched while Iraqi forces crushed dissident movements that the United States itself had encouraged.

In fact, international law became a barrier to effective action. Its protection of the principle of state sovereignty made it more difficult for the United States to take action to protect the Kurds and Shiites in Iraq. While international law could legitimate an international mobilization to return an unjust Kuwaiti regime, it offered little support to the just aspirations of millions of Iraqis.

In the end, of course, the United States intervened on behalf of the Kurds-but not the Shiites. ${ }^{41}$ And the limited humanitarian assistance that did arise resulted from domestic political pressure, created largely by ample press coverage, not from international law. It makes no sense, however, to say that the United States could intervene in Iraq to help the Kurds return to their homes, but could not intervene to defend them in their villages and homes before they became refugees. The War's aftermath has shown that international law can be a stumbling block for rational policy decisions.

As we have witnessed in Eastern Europe, international crises will be increasingly driven by movements for self-determination among nationalist groups. The United States' misguided policy in the aftermath of the Gulf War, and the failure of the United Nations to take effective action, mean that for large segments of the world's population international law is likely to be a problem rather than a solution.

International law has existed far too long as a system devoted to the maintenance of the status quo. This has meant, first, the maintenance of state boundaries and, second, the maintenance of the existing regimes within

41. Intervention to protect the Shiites had to wait for more than a year. The timing of this intervention in late August of 1992 seems to have been related more to domestic politics than to a concern for human rights. 
those boundaries. If international law is to aid in the foundation of a new world order, it cannot simply carry forward these same two ends. It must focus instead on change and on securing just relations among peoples and their governments, rather than on maintaining the inviolability of state sovereignty.

\section{CONCLUSION}

In the end, the Gulf War provides a lesson in the failures of international law, even as it suggests the possibilities for a more successful future. While the failures of international law typify its troubled state in the modern era, the significance of the allies' response is cast in some doubt by the exceptional circumstances that made it possible.

What would change this situation and revitalize international law to match the possibilities revealed by the War? First, human rights must be established as the foundation of international law. None of the actions taken specifically in the name of international law had as their end the direct support of human rights. Indeed, the War was largely a disaster for human rights, not just in Iraq, but in surrounding countries as well. For human rights to be the end, however, state sovereignty must be displaced as the central value of the international legal system. Focus on the state must give way to closer differentiation between interests of peoples and governments. This, in turn, cannot be achieved without reestablishing the connection between international law and war crimes, a connection that was born in, and died at, Nuremberg. ${ }^{42}$

Surprisingly, there has been little discussion of prosecuting the Iraqi leadership for war crimes. Instead, the international community has allowed Saddam Hussein to hold the Iraqi people hostage. The penalties directed at his regime place their costs on the people. The Iraqi people continue to suffer, instead of those responsible for the illegal actions. International law will not be taken seriously as a constraint on government policy as long as illegal behavior is divorced from personal consequences. Only criminal prosecutions can effectively separate international law from the self-interests of state governments.

Second, state sovereignty must yield not only to an ideal of human rights but also to an understanding of global interdependence. For example, there has been a striking failure of international law to recognize the environmental consequences of the Gulf War. Iraq's actions with respect to the oil wells and the waters of the Gulf caused a major environmental disaster. While some provision for compensating for these damages and other costs is envisioned if and when Iraq chooses to sell oil again, on the whole we have had silence on this issue. International law remains more concerned with nineteenth century ideas of state sovereignty than with contemporary under-

42. See generally Paul W. Kahn, From Nuremberg to the Hague: The United States Position in Nicaragua v. United States and The Development of International Law, 12 YALE J. INT'L L. 1 (1987) (critiquing the development of international law since Nuremburg). 
standings of the fragile character of all our lives on this planet. This too must be corrected if international law is to speak realistically and effectively in a new world order.

If the new world order does nothing more than add a few more states to the existing system of state sovereignty, it will soon resemble the old order. We have little reason to expect the next generation of political leadership to be more successful at maintaining respect for state sovereignty than was the last generation. More important, we do not yet have a good reason to respect such a rule, or a legal system founded on it. We will not have such a reason until there is a better match between the demands of justice and human rights on the one hand and state sovereignty on the other. At present, these goals often point in opposite directions. 